\title{
The scope of methodology transformation for human development management determining an increase in business effectiveness of investments in training projects
}

\author{
Paweł KOPIJER \\ Wyższa Szkoła Biznesu w Dąbrowie Górniczej, Poland
}

\begin{abstract}
:
Aim: The aim is to show market indications with respect to how to alter training investment management so that to improve the impact of training on the organization's performance. The topic is important because the effectiveness of business practice in training processes in Polish organizations continues to be poor due to the lack of benchmarks in the form of good practices or research.
\end{abstract}

Design / Research methods: The paper cites research findings which illustrate the existing practice of training management in Polish companies, as well as studies allowing for identification of the key indications for changes. The research methods employed in the findings cited belong to the category of pragmatic methods drawing on quantitative data gathered based on a questionnaire and quantitative and qualitative data gathered on the basis of an interview. The data stemming from the research cited are obtained through a subjective interpretation of the existing processes and phenomena.

Conclusions / findings: TDI Study shows that the following are the weakest link in training processes. The area of evaluation from the perspective of assessing how the training affects the firm's performance. The area of managers' commitment during the stage of applying competences on the job. The study of Indications for Training Process Transformation shows that the crucial change for an organization in the context of improving business effectiveness of training is to shift the focus of the analysis of needs from being centered solely on the competence gap towards identifying potential impact of training on business performance. The most realistic change involves introducing tools designed for managing the implementation phase and building awareness among participants that training is not merely an element of knowledge acquirement but an obligation to change behaviors with this change yielding business advantages for the company.

Contact details: Paweł Kopijer, Wyższa Szkoła Biznesu w Dąbrowie Górniczej, Ul. Cieplaka 1C, 41-300 Dąbrowa Górnicza, Poland. E-mail: pawel@kopijer.pl.

Received: 07.11.2016, Revised: 20.01.2017, Revised: 03.09.2018, Accepted: 03.09.2018

DOI: http://dx.doi.org/10.29015/cerem.323 
Originality / value of the article: The value of the paper lies in using benchmarking studies, the only ones in the Polish market, within the area of training policy effectiveness, and referring them to an innovative methodology of training project management. The findings and conclusions are of interest mainly for people who are responsible professionally for training management in that they allow for narrowing down the focus of actions aimed at improvements in the field of managing personal development.

Implications of the research: The findings show how to redesign optimally the training schemes in organizations. Within a general scope, they suggest those areas within training management which, if improved, should have the strongest impact on business outcomes.

Limitations of the research: The research limitations stem from employing subjective self-assessment as well as from the considerable impact exerted by industry-based characteristics

Key words: training policy, training effectiveness, training assessment

JEL: M53

\section{Introduction}

While analyzing management practices for training processes in Polish organizations one can notice a certain paradox.

On the one hand, the development of employees is recognized as an important determinant of the organization's success. This is demonstrated by such studies as, for example, Global Human Capital Trends 2016. The new organization. Different by design published by Deloitte University Press (Bersin et al. 2016), where a ranking of the top ten most important human capital trends was carried out using a sample composed of 7000 respondents from over 130 countries. In terms of its importance, learning was ranked in the fifth place according to senior executives and HR managers, accounting for $84 \%$ responses stating that it was "important" or "very important" ( $83 \%$ of responses for Central and Eastern Europe). As emphasized in the report, "learning opportunities are among the largest drivers of employee engagement and strong workplace culture - they are part of the entire employee value proposition" (Bersin et al. 2016: 4-6).

On the other hand, training, as one of the typical instruments for investing in human development in an organization, is poorly managed. This picture emerges, for instance, from the findings of the research on Benchmarks for Training Policy Effectiveness (TDI Study) that the Polish Society for Training and Development 
(PSTS) conducted for five years. The main indices from the Training and Development Integrity (TDI) group, illustrating the effectiveness of organizational practices in Polish companies are at a relatively low level: TD-M index, 59\% of the maximum score in the field of training project management effectiveness, TD-P Index, in the field of partnership efficiency for development, was $66 \%$ of the maximum score, and TD-E Index with only $40 \%$ of the maximum score for effectiveness of evaluation schemes (Kopijer et al. 2016: 5).

While identifying considerable development potential for improving the methodology of training process management, the paper cites specific findings produced by several studies in order to define market indicators for increased business effectiveness of training. This effectiveness is here conceived of as "the strength of the training project impact on the firm's business performance." The perspective that is considered here pertaining to the model solutions used in research mechanisms and in the interpretation of findings draws on several globally recognized models used in the context of the effectiveness of training process management. The models that should be mentioned here at the least are as follows:

- Donald Kirkpatrick's four levels evaluation model (Kirkpatrick 2001).

- Leslie Rae's training model (Rae 2001).

- Leslie Rae's training evaluation quintet (Rae 2001).

- Jack Philips' model for estimating ROI of training as well as the original SEB/SEA model (Kopijer 2011: 24-31).

\section{Description of the studies conducted}

\subsection{The aim of the individual studies}

The aim of the TDI Study is to create the possibility for assessing the state of effectiveness of training processes of a firm in relation to model solutions as well as of comparing it to market practices of other organizations in the same market. Drawing on Training and Development Integrity Model (TDI Model), the TDI Study makes it possible to assess comprehensively all the key processes in the field of training and development policy (see Figure 1) 
Figure 1. Elements of TDI Model (Model for Training and Development Integrity in an organization)

\begin{tabular}{|c|c|c|}
\hline $\begin{array}{l}\text { Audit Policy } \\
\text { TDI benchmark }\end{array}$ & $\begin{array}{l}\text { System of continuous } \\
\text { improvement }\end{array}$ & Training quintet model \\
\hline $\begin{array}{l}\text { - Automatic improvement } \\
\text { - Effectiveness of improvements } \\
\text { - Effectiveness of the system } \\
\text { - Audit comprehensiveness } \\
\text { - Cohesive training policy }\end{array}$ & $\begin{array}{c}\text { Training project } \\
\text { implementation standard }\end{array}$ & $\begin{array}{l}\text { - partnership quality of } \\
\text { management staff } \\
\text { - the quality of the role played } \\
\text { by senior executives } \\
\text { - the quality of cooperation } \\
\text { with contractors } \\
\text { - the quality of partnership } \\
\text { between employees } \\
\text { - optimization of the role of the } \\
\text { training department }\end{array}$ \\
\hline SEB/SEA model & & $\begin{array}{l}\text { SEB/SEA Mode } \\
\text { ROI model }\end{array}$ \\
\hline $\begin{array}{l}\text { - Quality of the phase of the } \\
\text { training needs analysis } \\
\text { - Quality of the training design } \\
\text { phase } \\
\text { - Quality of the phase of } \\
\text { preparing change } \\
\text { - Quality of the phase of } \\
\text { accounting for the project }\end{array}$ & $\begin{array}{c}\text { Partnership on training } \\
\text { Assessment of training } \\
\text { effectiveness and efficiency } \\
\text { Diagnosis of training needs }\end{array}$ & $\begin{array}{l}\text { - the quality of evaluating the } \\
\text { level of motivation to change } \\
- \text { the quality of evaluating } \\
\text { increases of competences } \\
\text { - the quality of evaluating the } \\
\text { level of competence } \\
\text { implementation } \\
\text { - the quality of evaluating } \\
\text { business benefits } \\
\text { - the quality of evaluating ROI } \\
\text { of training projects }\end{array}$ \\
\hline Strategic Process Scheme & & $\begin{array}{l}\text { Typology of training needs - } \\
\text { U scheme }\end{array}$ \\
\hline $\begin{array}{l}\text { - Alignment with business } \\
\text { strategy } \\
\text { - The quality of strategy } \\
\text { provisions } \\
\text { - Soundness of the strategic } \\
\text { analysis } \\
\text { - The quality of communicating } \\
\text { the strategy } \\
\text { - Strategic decision acceptability }\end{array}$ & Training strategy & $\begin{array}{l}\text { - business accuracy of diagnosis } \\
\text { - the quality of data produced } \\
\text { - cost effectiveness of IPS } \\
\text { system } \\
-\quad \text { user's acceptability of the } \\
\text { system } \\
\text { - sustainability of the training } \\
\text { budget }\end{array}$ \\
\hline
\end{tabular}

Source: Kopijer (2013: 86-88).

The aim of the study on the Structure of Reasons for Training Ineffectiveness is to produce a statistical picture of these actions within the training processes which are indicated by HR practitioners as being primarily responsible for the lack of impact of training on the organization's business performance.

The aim of the study on the Hierarchy of Indications for Training Process Transformations is to obtain market information from the perspective of HR 
practitioners and managers in the context of prioritized changes whose implementation in the field of training and development policy may provide a major stimulus for improved effectiveness of the impact exerted by development projects.

\subsection{Description of population under study and the tools applied}

All the studies whose findings are cited here were conducted predominantly on a group of people responsible for HR in organizations operating in the Polish market; however, to some extent they were also carried out within the community of managers and coaches (only within the TDI Study respondents were exclusively persons from HR in charge of development processes).

In the TDI Study, the scores of 524 firms in total were taken into account with those firms being engaged in various industries and coming from different regions, with the firms' sizes ranging between small, medium and large (79\% were made up of large organizations with over 250 workforce. Middle-sized organizations employing between 50 and 250 workers accounted for 19\%, with small organizations employing up to 50 workers accounting for $2 \%$.

The method for collecting data in the TDI Study is a set of survey questionnaires including 25 statements for each of the area investigated (meta-processes of training policy) describing a specific spectrum of actions that are important from the perspective of efficiency of the impact of learning on the organization's business performance. While evaluating learning practices in their organizations, respondents obtain point score, with the score being the higher the more business effective those practices are. An answer ticked in the questionnaire can produce between 0 and 4 points for each statement from the 25 statements available in each area, which means that in total the maximum of 100 points can be achieved for one single area. The number of points to be scored depends on the level of effectiveness and the quality of activity declared by respondents, it being the factual practice that is in force in the firm.

The market benchmark is an arithmetic mean produced based on the point scores achieved by all the firms participating in the study. In the paper, I present the studies concerned with only three areas:

- Effectiveness of the Standard of Training Project Management 
- Training Partnership Effectiveness

- Training Evaluation Scheme Effectiveness

While examining the Structure of Reasons for Training Ineffectiveness and within the study concerned with the Hierarchy of Indications of Training Process Transformation, the statements which were taken into consideration were those of 127 people in total who participated in various open and closed courses on Management of Training Processes. Within this population, (considering the official job positions) $74 \%$ were persons responsible for the organization's HR, with $16 \%$ being made up of business coaches, while $10 \%$ were composed of persons holding managerial posts not directly connected to HR.

The method for collecting data in the study on the Structure of Reasons for Training Ineffectiveness was for persons participating in courses to indicate all the situations where courses were ineffective in their organizations and to specify why. Next, the set of the reasons thus identified was structured in that a category was defined for the reasons having a similar source with the set being then grouped within these categories, the final statistic shows the percentage of indications which were allocated to a given reason-of-ineffectiveness category. Over $98 \%$ of all the indications as to the reasons was allocated to some of the categories.

The method for collecting data in the study of Hierarchy of Indications of Training Process Transformation was for the persons participating in courses to indicate only one prioritized indicator of training policy transformation which, in their view, would be critical for improving the effectiveness of training in their organizations, and one which would be for them the most realistic to implement in their occupational practice. The participants of this poll voted on one point elected from the list of $10 \mathrm{key}$ trends of training process transformation with the list being prepared based on an Expert Panel with participation of experienced HR consultants who had implemented various types of solutions in hundreds of organizations over the last decade. 


\section{The results of the study}

\subsection{TDI Study results}

Chart 1 below shows the benchmark (arithmetic mean of the scores achieved by all the firms participating in the study) within the area of Training Project Management Standard produced in the Polish market in 2015. On the radar chart, one can see the evaluation of the effectiveness of market practices with this effectiveness being broken down into individual subsequent phases of the training project from the analytical phase, designing the process, preparing to change, implementing new concepts to the final evaluation of the project (see Chart 1). The single axe illustrating the effectiveness of actions performed within the phase concerned has a scale from 0 to 20 points, which is the maximum a firm can achieve (in the survey questionnaire there are five statements within the given phase with each statement allowing for gaining a maximum of 4 points, thus giving 20 points in total in the evaluation of a particular phase - in the nomenclature of the TDI Study, it is called the evaluation of "training process dimension."

\section{Chart 1. The Structure of the effectiveness Benchmark of the Training Project Management Standard}

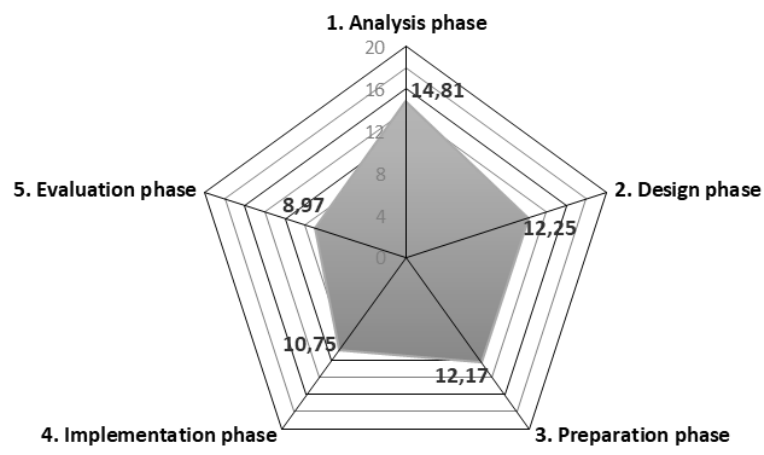

Source: Kopijer et al. (2016: 6).

The basic conclusion to be drawn from the findings elicited in this part of the study is that the overall evaluation of the practices employed in training 
management in Polish firms ranks rather poorly (less than $60 \%$ of the ideal state). Although this score is not alarming yet, it certainly shows that we have a considerable development potential in terms of improving the effectiveness of training schemes (what would be very interesting is to compare Polish benchmarks with the European, but for this the data are not yet available). Organizations which gained the highest score within this area of the study, with scores at a maximum of $95-98 \%$, made up barely $4 \%$ of the population surveyed. This sends out a signal that not only is there a considerable potential in the economy to improve this critical, as can be gleaned from numerous reports, area of management but also that, in the Polish market, we have good practices in this field and firms from which others can learn.

Yet another reflection that comes in this respect is that some tendency can be observed on the above radar chart. Each subsequent phase of the training process is implemented increasingly less effectively. This could suggest that the engagement of persons responsible for the training process weakens along with its implementation, with the lowest score being gained in the evaluation phase and accounting for the training investment. This may also be a signal that controlling the training impact on employees' behavior and examining the business consequences arising from this change are not a priority for managers.

The next chart shows the benchmark in the area of Training Partnership produced in the Polish market in 2015. One can see on the radar chart the evaluation of effectiveness of market practices as broken down into individual partners who are to play defined roles in the training process through performing specific tasks which determine the ultimate business success of the entire project (see Chart 2). The single axe illustrating the effectiveness of actions in the phase concerned has a scale from 0 to 20 points, the maximum that a firm can gain (in the survey questionnaire there are five statements within the given phase with each statement allowing for gaining a maximum of 4 points, which gives 20 points in total in the evaluation of the particular phase - in the nomenclature of the TDI Study, it is called the evaluation of "training process dimension" 


\section{Chart 2. The Structure of the effectiveness Benchmark of Training Partnership}

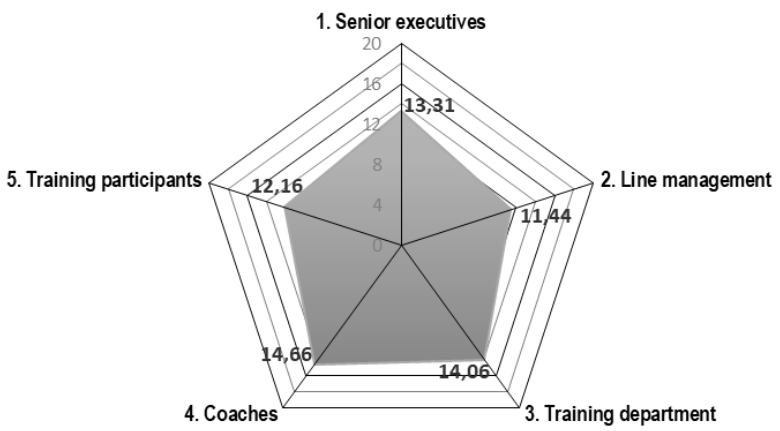

Source: Kopijer et al. (2016: 9).

The conclusion that comes to the fore in this section of the study is that the evaluation of practices within the field of the division of tasks and roles among different partners within training processes ranks significantly better than the evaluation in terms of the effectiveness of the actions themselves from the previous chart (7 percentage points better than the benchmark for the Training Project Management Standard). Although here the general score falls short of the very good score, what can be seen is that the different parties to the project who cooperate with one another on a daily basis are fairly well equipped, in terms of their awareness of their role and responsibility, to achieve good results in terms of the impact of the training on the organization's business performance. One can therefore assume that the environment of the relationships unfolding between people responsible for HR, managers, employees and coaches fosters cooperation and allows for yielding potentially better effects.

The last radar chart of those presented here shows the benchmark in the area of the effectiveness of Training Evaluation Scheme. One can see on the radar chart the evaluation of the effectiveness of market practices broken down into individual spheres of actions monitoring the impact of the training, from the evaluation of participants' reaction to the training change awaiting them (evaluation of peoples' 
motivation to change), assessment of the progress of the competences acquired, the effectiveness as to the application of new behaviors and solutions on the job, to the evaluation of business advantages generated by the training project and ultimately assessing their value adopting a financial approach through, for instance, estimating ROI of the entire training investment (see Chart 3).

\section{Chart 3. The structure of the effectiveness Benchmark for Training Evaluation Scheme}

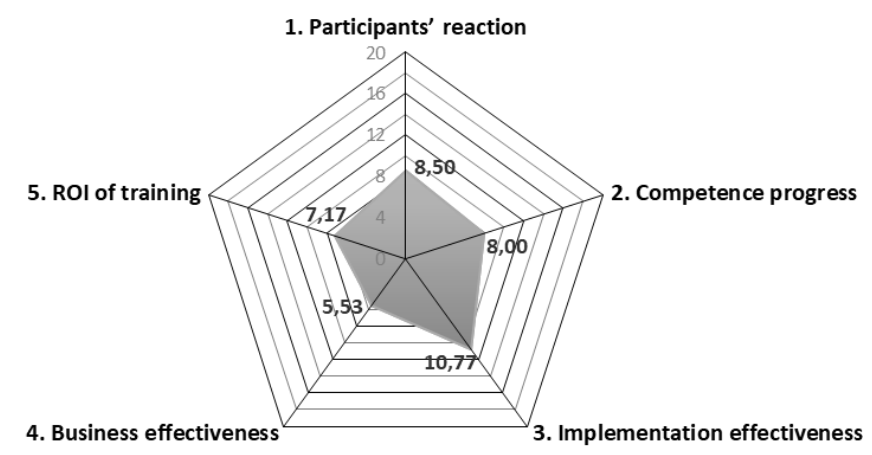

Source: Kopijer et al. (2016: 12).

What appears striking in the first place when looking at the chart above is the overall evaluation of the training policy, given that it is substantially lower in comparison to the two previous evaluations (19 percentage points lower than the score for Project Training Management Standard and as many as 26 points less than the Training Partnership benchmark). This might suggest a picture where a fairly large potential exists in terms of cooperation between the training process partners with quite many good practices present in Polish firms at the initial phases involving identifying and designing training, yet hardly any attempts are made at checking whether all this effort leads to any kind of outcomes for the organizations. In considering, as a context, any kind of Project Management methodology, that would imply that the training processes in organizations are being very poorly managed. Moreover, looking from the purely business and financial perspective, this could be 
interpreted as common mismanagement and failing to check on the investment discount. A much better interpretation would certainly be produced by in-depth analyses carried out already at the sub-benchmark level in relation, for example, to the individual single statements from the research survey questionnaire (see the attachment).

Moreover, what may also prove interesting is the data on the effectiveness of training processes broken down into size classes of employment of the firms partaking in the study. The chart below presents the comparison of sub-benchmarks produced for the individual phases of the training project by organizations varying in the size of employment (see Chart 4). The firms' four size classes (understood as the total number of posts held by the firm at the moment of its participation in the study) are compared with the overall score for the entire population.

\section{Chart 4. Comparing sub-benchmarks of firms varying in size classes of employment}

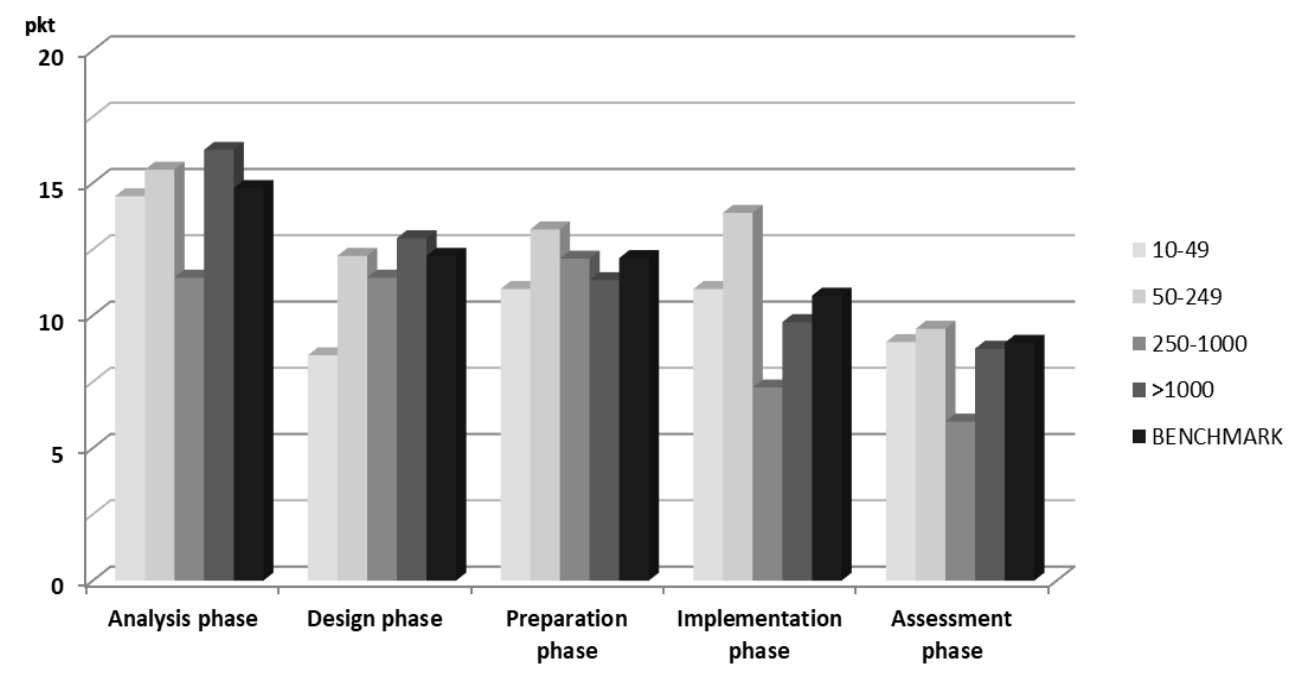

Source: Kopijer et al. (2016: 18).

As can be gleaned from the chart above, the largest organizations which have a workforce of over 1000 can boast of best practices in terms of actions performed in the analysis phase and design phase, while the other phases are dominated by the practices of medium-sized businesses employing a workforce ranging between 50 
and 250. These firms are precisely those which fare the best in the overall assessment. Interestingly, the firms which fare the worst in this comparison are large companies whose staff, however, does not exceed 1000 people.

This could suggest that in principle the scale of employment is very relevant to the effectiveness of training process management. Smaller firms have better practices provided they have their own specialized cells responsible for training and which employ experts in this field (the observable threshold at which organizations have their own training department is a workforce of 80-100), while large firms have growing problems to manage training processes effectively unless they are corporations with schemes and tools devised drawing on their indigenous practices, having considerably expanded structures of training specialists who use largely their own resources while conducting training (as regards the origins of the capital, foreign firms with Polish private capital fare the best in the overall assessment) (Kopijer et al. 2016: 5).

\subsection{The results of the study on the Structure of Reasons for Training Ineffectiveness}

The chart below depicts the results of the study focused on identifying the most common reasons of lacking effectiveness of training conducted in firms through the prism of experiences and observations of trainers, those responsible for training, HR representatives, business coaches as well as operational managers (see Chart 5).

As the individual indications were not weighted (for example, the extent of the impact on the training effectiveness) and instead the indications falling within the individual categories were merely counted, the percentage distribution produced can only be seen as estimated indication as to which reasons are generally of key importance for the effectiveness of training rather than an internal comparison in terms of the level of significance. Perhaps the frequency with which a particular category is indicated by respondents may be a general indication of which category from those presented below is more crucial than the other. A valid parameter of the structure is the minimal margin of indications which were not included in the structure as they were single indications, as well as a relatively substantial level of consistency with the findings produced by other studies cited in this paper. 


\section{Chart 5. The structure of the most frequent reasons for ineffectiveness of training conducted in firms}

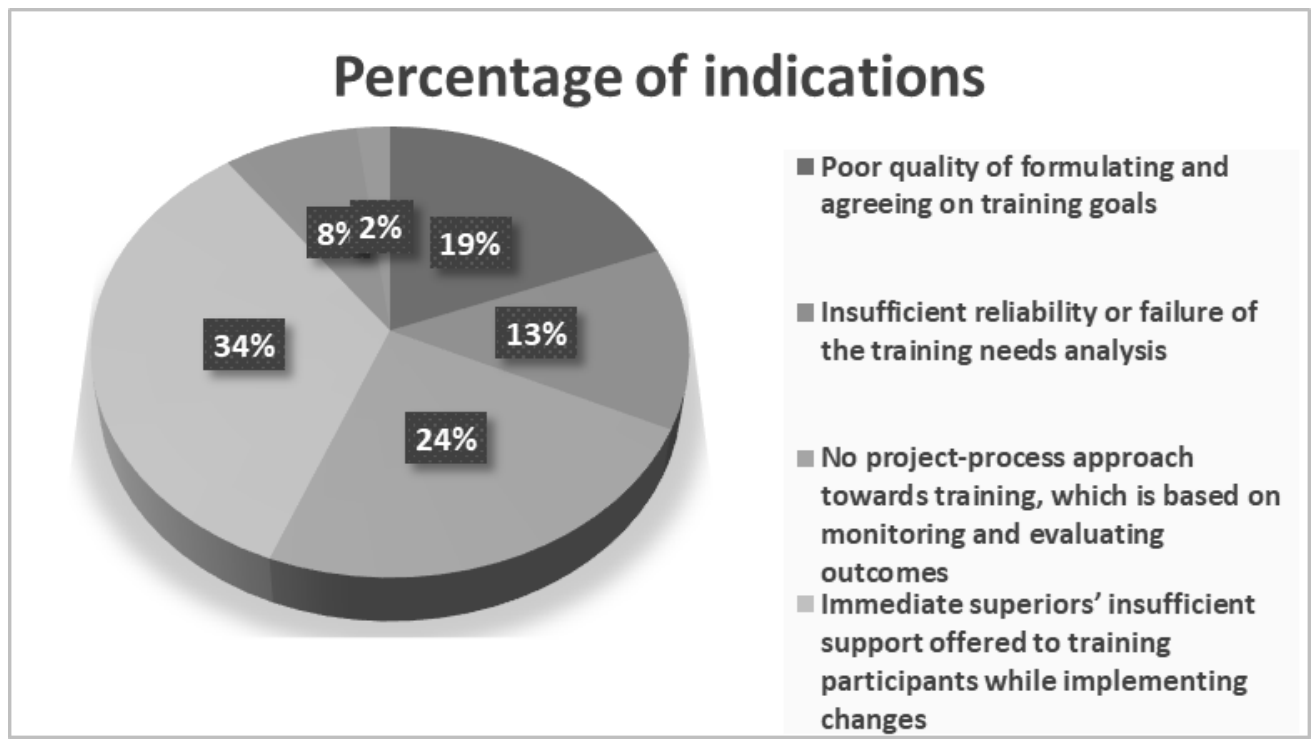

Source: author's own research.

The above chart shows that the most frequent reason for the lack of business effectiveness of the training is insufficient commitment on the part of managers who are the training participants' immediate superiors, especially during the phase when the new competences acquired in the training are being applied on the job. This is reflected in the findings produced by the TDI Study on the effectiveness of Training Partnership where the management staff displays the lowest level of awareness and willingness to exercise their own role. Clear consistency with the TDI Study findings is also visible in the second most frequently reported reason, which is the lack of a project approach and thus related evaluation actions. Although the scores of the market benchmarks show a relatively better overall assessment of the practices within the analysis phase (where the goals of the training project are also set), the frequent indication of the poor quality of training goals and insufficiently reliable analysis as the reason for the training failing to be effective is connected entails worse practices which refer purely to setting indicators for the business 
impact of training. These indicators should be precisely defined already at the stage of the analysis of needs as an element of evaluation measures (setting indicators for monitoring business effectiveness of training investment).

\subsection{The results of the study on the need of changes within the training policy from the perspective of managers and HR experts - Indication Hierarchy of Training Process Transformation}

Charts 6 and 7 below refer to indications made by trainers, those responsible for training, HR representatives, business coaches and operational managers with regard to a list of 10 key trends in the transformation of training processes (see Table 1) and which was prepared by experts advising hundreds of organizations in this area.

The two charts below are a statistical picture of what persons who are responsible for being engaged in training management in Polish organizations think about the changes in the approach towards training from the perspective of the following two questions:

- Which of the trends mentioned is the most important for your organization in the context of improved business effectiveness of training events?

- Which of the trends mentioned can be used most realistically in your organization in the foreseeable future?

- As can be gleaned from the chart, according to respondents' assessment, the most important trend for their organization would be the aspect of refocusing the training needs analysis, shifting it from its sole emphasis on the competence gap towards recognizing the potential impact of training on business outcomes and the relationships between those outcomes and the change in employees' behavior (see Chart 6). Another important aspect is shifting the responsibility for the training effects onto participants themselves and their immediate superiors while making the self-same participants aware as to what the organization expects of them when delegating them to participate in training.

- The above findings are to some extent consistent with the practices identified earlier and relating to the shortcomings of the manager role as well as linking training insufficiently with the organization's business needs. 
Table 1.10 key trends in the transformation of training processes

\begin{tabular}{|c|c|}
\hline $\begin{array}{l}\text { Training practice ineffective in business } \\
\text { terms }\end{array}$ & Training practice effective in business terms \\
\hline $\begin{array}{l}\text { 1. Accent on the implementation quality of } \\
\text { didactic classes }\end{array}$ & $\begin{array}{l}\text { 1. Accent praced on business enrectiveness } \\
\text { of the project }\end{array}$ \\
\hline $\begin{array}{l}\text { 2. The goals of the training are general and } \\
\text { mainly relate to competences }\end{array}$ & $\begin{array}{l}\text { 2. The goals of the training are in line with } \\
\text { SMART principle and in relation to all } \\
\text { Kirkpatric levels }\end{array}$ \\
\hline $\begin{array}{l}\text { 3. The training needs analysis focuses on } \\
\text { identifying the competence gap and } \\
\text { determinants for attractive classes }\end{array}$ & $\begin{array}{l}\text { 3. The training needs analysis which stems } \\
\text { from the business need recognizing the } \\
\text { relationships between business advantages } \\
\text { and behavior }\end{array}$ \\
\hline $\begin{array}{l}\text { 4. Negotiation of the rate for performing } \\
\text { classes (training day) }\end{array}$ & $\begin{array}{l}\text { 4. Partnership negotiations with the } \\
\text { possibility of a success fee depending on } \\
\text { the business effect }\end{array}$ \\
\hline $\begin{array}{l}\text { 5. Effectiveness evaluation based mainly } \\
\text { on the questionnaire following the training } \\
\text { which evaluates the quality and } \\
\text { attractiveness of the classes }\end{array}$ & $\begin{array}{l}\text { 5. Training assessment is based on } \\
\text { estimating ROI * or ROI business } \\
\text { effectiveness and efficiency }\end{array}$ \\
\hline $\begin{array}{l}\text { 6. The participant can seldom count on real } \\
\text { support on the part of his/her superior } \\
\text { while applying new competences }\end{array}$ & $\begin{array}{l}\text { 6. The participant "contracts" with his } \\
\text { superior to work on changing and } \\
\text { improving hi/her work performance based } \\
\text { on new competences }\end{array}$ \\
\hline $\begin{array}{l}\text { 7. No possibility of evaluating the impact } \\
\text { of training on business outcomes of the } \\
\text { training }\end{array}$ & $\begin{array}{l}\text { 7. Evaluation of the training impact on } \\
\text { business outcomes of the training is } \\
\text { relatively easy and "automatic" }\end{array}$ \\
\hline $\begin{array}{l}\text { 8. The responsibility for the training effects } \\
\text { is borne by the coach and HR }\end{array}$ & $\begin{array}{l}\text { training effects } \\
\text { heir superiors }\end{array}$ \\
\hline $\begin{array}{l}\text { 9. Participants are very little or are not } \\
\text { aware at all of what the training is to bring } \\
\text { to the firm }\end{array}$ & $\begin{array}{l}\text { are fully aware of what is to } \\
\text { esult of the training and what } \\
\text { l expectations of them }\end{array}$ \\
\hline $\begin{array}{l}\text { 10. No actions or only trace actions aimed } \\
\text { at applying the competences on the job } \\
\text { following the didactic classes }\end{array}$ & $\begin{array}{l}\text { 10. Planned and managed phase of applying } \\
\text { the competences on the job following the } \\
\text { classes }\end{array}$ \\
\hline
\end{tabular}

*ROI - financial indicator for return on investment

Source: author's own research. 
Chart 6. Percentage distribution of indications as regards the individual changes in the context of the question on its importance

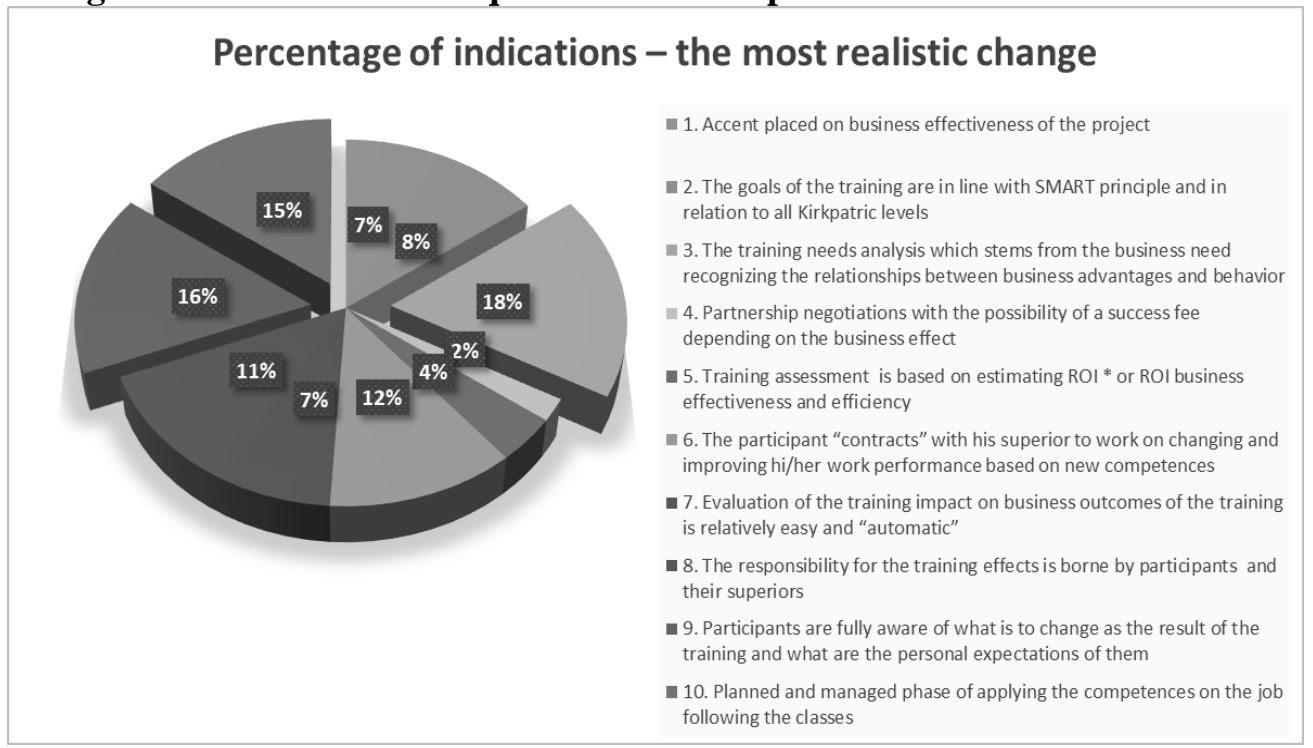

Source: author's own research.

Chart 7. Percentage distribution of indications as regards the individual changes in the context of the question on how realistic their implementation is

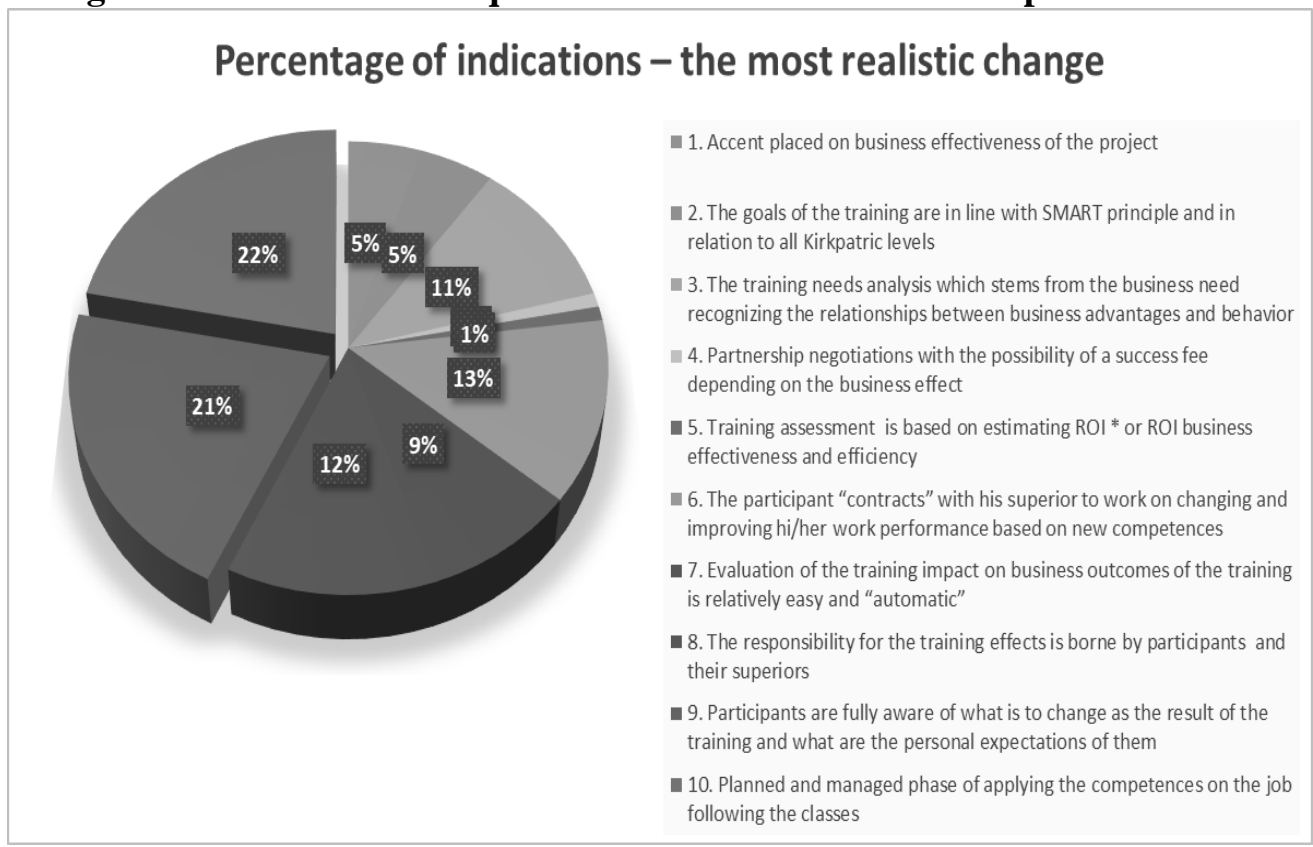

Source: author's own research. 
With respect to how realistic for organizations is the implementation of potential changes with a view to improve training events effectiveness, what is clearly underlined is the focus on applying tools for managing the implementation phase and on building participants' awareness that training is not merely an element of acquiring knowledge, for it is an obligation to change behaviors in order to bring about business benefits to the organization (see Chart 7).

\section{Concluding remarks}

Taking into account the market indications for changing the training management methodology in organizations, as well as considering the findings of the Polish-wide TDI Study, what is clearly delineated is the need to shift the standard of employee development management towards specific management control. Evaluation understood as monitoring effects at individual stages of the training process change becomes a requirement for generating a business impact of the investment in the Human Capital development. What also changes is the imperative for the roles played by the manager who is in the position of an immediate superior of the training participant and for the participant himself. Their awareness of the responsibility and the need of personal commitment to safeguard the training impact on the organization's business outcomes also shows a signal to transform the role played by the training department or HR. The training department should become a "catalyst" for the transformation of training schemes and the reinforcement for management staff rather than being a direct and sole operator of training events. 


\section{References}

Bersin J., Geller J., Wakefield N., Walsh B. (2016), Global Human Capital Trends 2016. The new organization: different by design, Deloitte University Press, https://www2.deloitte.com/content/dam/Deloitte/global/Documents/HumanCapital/gx-dupglobal-human-capital-trends-2016.pdf [07.12.2018].

Kirkpatrick D.L. (2001), Ocena efektywności szkoleń. Cztery poziomy oceny efektywności szkoleń, Studio EMKA, Warszawa.

Kopijer P. (2011), Kompendium zarządzania szkoleniami. Praktyczny przewodnik po inwestycjach w rentowność kapitału kompetencyjnego, Wydawnictwo SWPS Academica, Warszawa.

Kopijer P. (2013), Biznesowy wymiar szkoleń. Efektywność polityki rozwojowej w polskich organizacjach, „Personel i Zarządzanie”, no. 1, pp. 86-88.

Kopijer P., Ziaja M., Tadrała D., Burzyńska K. (2016), Raport rynkowy 2015. Ogólnopolskie Badanie Benchmarków Efektywności Polityki Szkoleniowej, Wydawnictwo PSTD, Warszawa.

Phillips J.J. (2010), ROI, czyli zwrot z inwestycji w szkolenia i rozwój kadr, Wydawnictwo SWPS Academica, Warszawa.

Rae L. (2001), Planowanie i projektowanie szkoleń, Dom Wydawniczy ABC - Oficyna Ekonomiczna, Kraków.

\section{Annex}

The survey questionnaire, TDI Study, Training Project Management area

\begin{tabular}{|c|c|c|}
\hline & & Training Project implementation standard \\
\hline & 1 & The training need analysis starts at the level of the organization's business need \\
\hline$\underset{\mathscr{Z}}{\tilde{\Xi}}$ & 2 & $\begin{array}{l}\text { The scope of support for training participants while applying competences is } \\
\text { planned before preparing a training program }\end{array}$ \\
\hline$\frac{2}{2}$ & 3 & $\begin{array}{l}\text { The need for training is arranged between the worker and his superior and is } \\
\text { consulted with the training department or the coach }\end{array}$ \\
\hline $\bar{\Xi}$ & 4 & The training goals which have been defined are formally recorded \\
\hline & 5 & $\begin{array}{l}\text { The training goals are communicated to all training partners: training participants } \\
\text { and their direct superiors, coaches }\end{array}$ \\
\hline & & $\begin{array}{ll} & \text { TOTAL }\end{array}$ \\
\hline 항 & & $\begin{array}{l}\text { While drawing up schedules, one also takes into consideration the time needed for } \\
\text { applying the new competences on the job }\end{array}$ \\
\hline हैं : & & $\begin{array}{l}\text { The evaluation of the training in terms of its effectiveness and efficiency is an action } \\
\text { planned before didactic classes }\end{array}$ \\
\hline
\end{tabular}




\begin{tabular}{|c|c|c|}
\hline \multirow{3}{*}{ 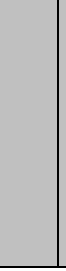 } & \multirow{3}{*}{$\begin{array}{l}3 \\
4\end{array}$} & \multirow{2}{*}{$\begin{array}{l}\text { The contractor is chosen based on formal procedures for choice optimization } \\
\begin{array}{l}\text { In order to ensure all the necessary resources needed for successful implementation } \\
\text { of a training project Checklists are used }\end{array}\end{array}$} \\
\hline & & \\
\hline & & $\begin{array}{l}\text { A set of evaluation tools is prepared before launching didactic activities } \\
\text { (e.g. the questionnaire of reactions, knowledge/skills test, implementation and goal } \\
\text { achievements evaluation form) }\end{array}$ \\
\hline & & $\begin{array}{ll} & \text { TOTAL }\end{array}$ \\
\hline \multirow{5}{*}{ 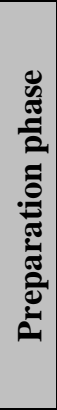 } & \multirow{5}{*}{$\begin{array}{l}1 \\
2 \\
3 \\
3 \\
5\end{array}$} & $\begin{array}{l}\text { Training participants are motivated to participate in didactic classes in that they are } \\
\text { shown the benefits arising from an effective performance of work }\end{array}$ \\
\hline & & $\begin{array}{l}\text { In order to raise didactic classes effectiveness, training participants are given and } \\
\text { perform pre-training work }\end{array}$ \\
\hline & & $\begin{array}{l}\text { Didactic classes end with planning how the training participants can use the } \\
\text { competences on the job }\end{array}$ \\
\hline & & $\begin{array}{l}\text { The training program is arranged in relation to the defined change that is to occur in } \\
\text { the participants' actions following the classes }\end{array}$ \\
\hline & & $\begin{array}{l}\text { During classes, training participants work out on specific materials to be used later } \\
\text { on the job (e.g. questionnaires, checklists, knowledge base, procedures) }\end{array}$ \\
\hline & & $\begin{array}{lc} & \text { TOTAL } \\
\end{array}$ \\
\hline \multirow{5}{*}{ 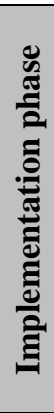 } & \multirow{5}{*}{$\begin{array}{ll}1 \\
2 \\
3 \\
3 \\
5\end{array}$} & $\begin{array}{l}\text { The ideas of how to apply competences on the job, the training planned by the } \\
\text { participant are arranged with his/her superior }\end{array}$ \\
\hline & & $\begin{array}{l}\text { Support for training participants is arranged which they will need while attempting } \\
\text { to use the new competences on the job }\end{array}$ \\
\hline & & $\begin{array}{l}\text { Training participants are reinforced while applying the new competences on the job } \\
\text { following their return from the didactic classes }\end{array}$ \\
\hline & & $\begin{array}{l}\text { Within a specific period after the didactic classes, the effectiveness with which the } \\
\text { new competences are used is monitored }\end{array}$ \\
\hline & & $\begin{array}{l}\text { The ways of motivating training participants are arranged so as to make them use } \\
\text { their new competences as efficiently as possible }\end{array}$ \\
\hline \multirow{6}{*}{ 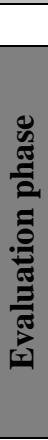 } & & $\begin{array}{ll} & \text { TOTAL } \\
\end{array}$ \\
\hline & 1 & $\begin{array}{l}\text { Training participants are appreciated by their organization for their efforts and } \\
\text { engagement in applying the competences acquired in classes on the job }\end{array}$ \\
\hline & 2 & $\begin{array}{l}\text { Once the training project has been completed, feedback is given on how the training } \\
\text { affected the organization's operations and performance }\end{array}$ \\
\hline & 3 & The actual use of the competences in practice on the job is evaluated \\
\hline & 4 & $\begin{array}{l}\text { There is training project closing documentation which contains a report on the } \\
\text { training impact on the firm's activities and performance }\end{array}$ \\
\hline & \multirow[t]{3}{*}{5} & $\begin{array}{l}\text { Indicators are calculated referring to increases in competences, efficiency of their } \\
\text { application and organization's improved performance }\end{array}$ \\
\hline & & TOTAL \\
\hline & & THE TOTAL OF THE AREA \\
\hline
\end{tabular}

